\title{
$\mathrm{W} \cdot \mathrm{K}$ ・バルトンが濃尾地震後に根尾谷で撮影した写真と撮影地点について 『THE GREAT EARTHQUAKE IN JAPAN, 1891.』の研究 その 6
}

\section{STUDY ON THE PHOTOGRAPH AND THE PHOTOGRAPHY PLACE PHOTOGRAPHED IN NEO VALLEY BY W. K. BURTON}

Study on “THE GREAT EARTHQUAKE IN JAPAN, 1891.” part 6

\author{
平山育男 ${ }^{* 1}$
}

\section{IkUo HIRAYAMA}

\begin{abstract}
This article considered the photograph which W. K. Burton photographed after the Nobi earthquake in Neo valley, and following points become clear.

There are at least six pieces (1) -6) of photographs which he photographed just after the earthquake in Neo valley. Photo(1) was shot the Danto bridge, Photo(2) was shot the Takao bridge, Photo(3) was shot the afflicted houses beside the Adati shrine, Photo(4) was shot the Neo river. Photo(5) was shot the fault caused by the Nobi earthquake at Midori. The shooting location of Photo(6) is unknown.
\end{abstract}

Keywords : the Nobi earthquake, W. K. Burton, Neo valley 濃尾地震, $\mathrm{W} \cdot \mathrm{K} ・$ バルトン, 根尾谷

\section{1.はじめに}

筆者はこれまで、明治 24(1891) 年 10 月 28 日に発生した濃尾地震 においてバルトンとミルンらが写真記録集としてまとめた『THE GREAT EARTHQUAKE IN JAPAN, 1891.』参考1)（以下、GEJ）に考察を 加え、初版、2 版の各 2 刷注1) の発刊日を示し注2)、掲載の被災地写 真 34 枚中 25 枚をバルトンが撮影したこと注3)などをまとめている。

ところで、GEJ所収の写真の内、根尾谷で撮影された4枚は具体的 な撮影地点が検討されていないものがある。一方、バルトンは被災

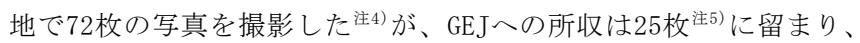
未所収の 47 枚に根尾谷で撮影した写真の存在する可能性がある注6)。 そこで本稿ではバルトンが根尾谷で撮影し、GEJ未所収の写真注7 も 示した上で、それらの撮影地点を明らかにすることを目的とする。

\section{2. バルトンが濃尾地震後に根尾谷で撮影したと考えられる写真}

以下、バルトンが根尾谷で撮影したと考えられる写真を示す。

\section{2-1 GEJ 掲載の写真}

バルトンが根尾谷の濃尾地震被災地において撮影した写真の内、 GEJ に所収されるのは初版 PLATE XVIII.（2 版 PLATE XIX.、以下、 Photo(1) 、初版 PLATE XIX. (2 版未所收、以下、Photo(2) 注8)、初 版 PLATE XX. (2 版 PLATE XXI. 、以下、Photo(3))、初版 PLATE XXI. (2 版 PLATE XXII.、以下、Photo(4)) の 4 枚で、写真題名は Photo
(1)、(2)が “BRIDGE IN NEO VALLEY.”[和訳 : 根尾谷の橋]、Photo(3) が “IN NEO VALLEY.”[和訳 : 根尾谷にて]、Photo(4)が “LAND SLIPS IN NEO VALLEY.”[和訳 : 根尾谷の地滑り]とあり、写真題名からい ずれも根尾谷での撮影と判明する。

\section{2-2 GEJ 未掲載でエ学会において投影された写真}

濃尾地震後、明治 24(1891) 年 11 月 25 日の工学会においてバルト ンは幻灯の投影と説明を行っている。ここでバルトンは

根尾谷ノ写真ニ移ル先ツ現ル、モノ八谷ノ一方八陥落シ他ノ一 方八二十英尺ノ高サニアルモノナリ次キニ現ハレタルハ其䢃裂 ノ線上ニアル家二ツニ分レ一部分ハ陥リテ他ノ部分ノ下ニアル 奇観ナリ注 99

と説明する少なくとも 2 枚の写真を提示した。“次キニ現ハレタル” 以下の後者は、バルトンが GEJ に Photo(3)として示したものに対応 するが、“谷ノ一方八陥落シ他ノ一方八二十英尺ノ高サニアルモノ” とする前者の情景はPhoto(1)、(2)、(4)にはなく、GEJ 未所収と言える。

ところで GEJ 所収の写真も含め、バルトンが撮影した写真の多く は宮内庁へ献納されたが、写真の版権は帝国大学注10) にあったため、 バルトンが撮影した写真の 2 次利用は極めて限定され、国立科学博 物館所蔵を除くと同時代における他写真集などへの転載は認められ ない注11)。そこで宮内庁所蔵の写真から、上掲した“谷ノ一方八陥 落シ他ノ一方八二十英尺ノ高サニアルモノ”とする内容を有し、か

\footnotetext{
*1 長岡造形大学造形学部 教授・博士(工学)、博士(造形) Prof., Faculty of Design, Nagaoka Institute of Design, Dr.Eng., Dr.Design
} 
つ 2 次利用のないものを探すと、“岐阜県下根尾谷地之之図” と題さ れる写真にその情景がある(以下、Photo(5) 注12)。但し、この写真に は宮内庁でも上掲の写真題名しかなく、詳細な解説はない。

\section{2-3 GEJ とエ学会において未発表で宮内庁に所蔵される写真}

宮内庁所蔵の濃尾地震被災地写真で、根尾谷を撮影し、2次利用の ないものに“岐阜県下根尾谷人家之図”（以下、Photo(6)）と題され されるものがあり注13)、これはバルトンによる撮影の可能性がある。

\section{3. バルトンが濃尾地震後に根尾谷で撮影したと考えられる写真の 撮影地点の検討}

このようにバルトンにより根尾谷の濃尾地震被苂地で撮影された と考えられる写真は GEJ 所収の 4 枚である Photo(1) (4)、GEJ 未所収 で宮内庁所蔵のPhoto(5)、(6)の 2 枚、合計 6 枚となる。しかし、こ れらの多くは従来、撮影地点は特定されていない。そこで、以下で は各写真の既往研究を挙げ、撮影地点の考察を行いたい。

\section{3-1 Photo(1)の撮影地点}

\section{3-1-1 Photo(1)の従来の研究}

Photo(1)は根尾谷における濃尾地震の被災状況を示寸ものとして、 これまで度々紹介されている。以下、その内容を見て行きたい。

\section{・『写真でみる濃尾震災』}

『写真でみる濃尾地震』注 14$)$ は、濃尾地震発生から 100 年目となる 平成3 (1991) 年に出版され、濃尾地震発生当時の写真が多数収録され る。同書ではGEJの写真を複数用い、本稿が扱うものではPhoto(1)、 (3)、(4)を転載する。この内、Photo(1)は “崩れ落ちた根尾谷の橋” と して掲載されるが、具体的な撮影地点の記載はない注15)。

・『三大地震と人々の暮らし 濃尾明治・関東大正・阪神・淡路現代』 『三大地震と人々の暮らし 濃尾明治・関東大正・阪神・淡路現代』

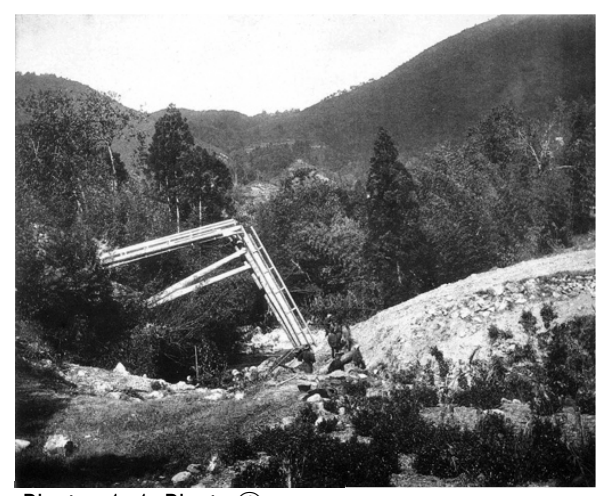

Photo 1-1 Photo(1)

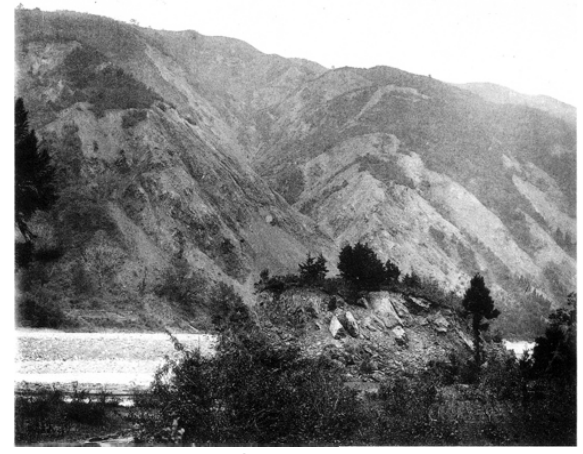

Photo 1-4 Photo(4)

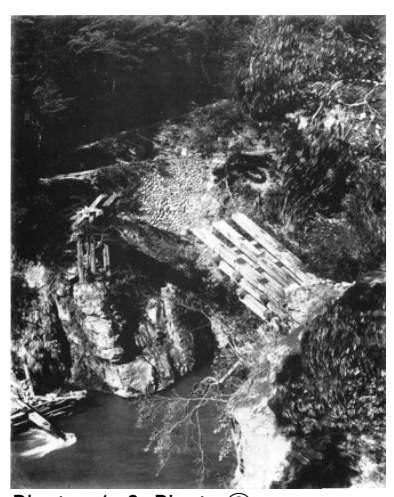

Photo 1-2 Photo(2)

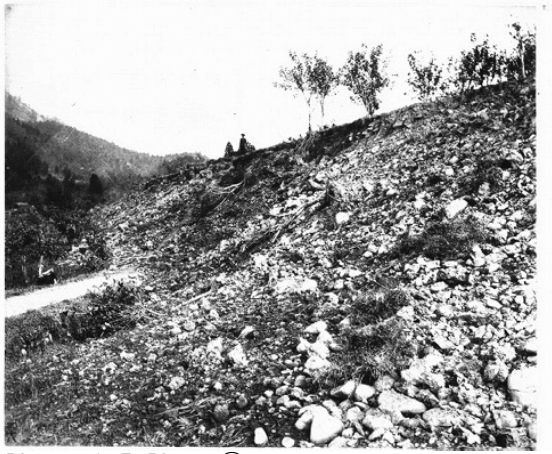

Photo 1-5 Photo(5) 宮内庁書陵部所蔵
注16）（以下、『三大地震と人々の暮らし』）は、阪神淡路大震災後の 平成8 (1996) 年に歴代の地震災害について写真資料を中心に紹介し たものである。濃尾地震についてはバルトンの曾孫にあたる鳥海幸 子からバルトンの所蔵に関わるGEJ2版1刷注17) の提供があり、本稿が 扱うものではPhoto(1)、(3)、(4)を転載する。

Photo(1)は同書で “根尾谷の橋” と題して示され、説明文も付され るが、撮影地点の記載はない注18)。

\section{・『1891濃尾地震報告書』附属CD-r}

『1891濃尾地震報告書』附属CD-rにおいてPhoto(1)は、GEJ2版1刷 を撮影したと考えられるmi1ne56及び、宮内庁に所蔵されるkunai 110 を所收する。この内、kunai110には“岐阜県下根尾谷落橋之図”之 する写真題名が付されるのみで、具体的な撮影地の説明はない注19)。

\section{3-1-2 Photo(1)の概要と読み取れる情報}

Photo(1)では近景に低木がある。中景には被災した木製橋桁の支柱 があり、何人かの人々も見ることができ、背後は竹藪、林となる。

遠景には山並みを確認できる。

3-1-3 Photo(1)の撮影地点の検討

Photo(1)に対応する解説をバルトンはGEJにおいて注20)

HERE we have a scene in the famous Neo Valley, $\cdots$ on the left of the picture a portion of a light cantilever bridge remain in position:

[和訳] 有名な根尾谷の光景である。《中略》画面左には、軽量 カンチレバー橋の一部が元の位置に残っているのが見える とあり、Photo(1)が根尾谷における橋の被災を示すことを示す。この 周辺の被災状况は、岐阜地方気象台に所蔵され

本巣郡日当村字ダント坂南西ヨリ北東二架ケアル橋破折東ヨリ 望么注21)

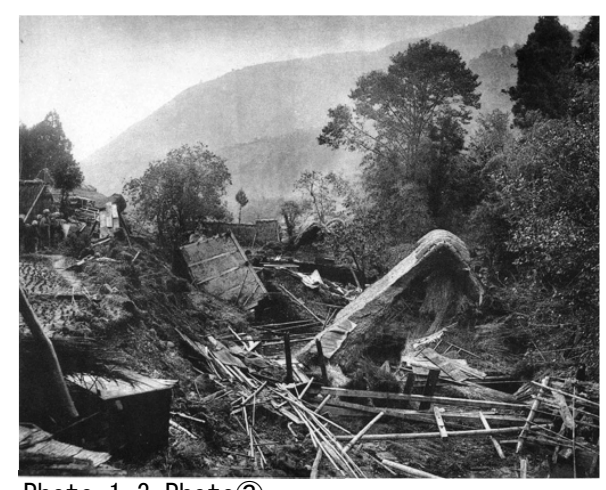

Photo 1-3 Photo3

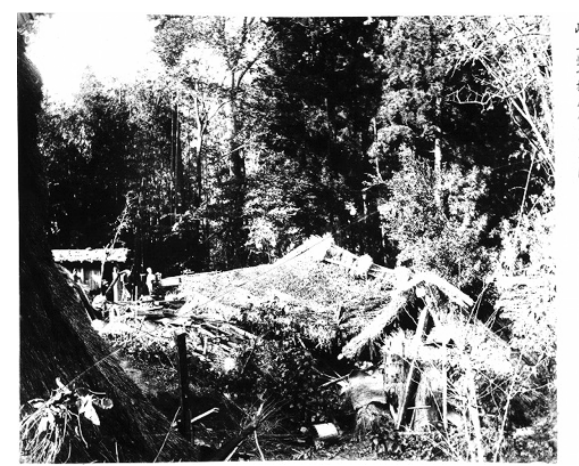

Photo 1-6 Photo6

宮内庁書陵部所蔵 
と題名の付された写真に示される橋と同一のものと考えられる。更 に、長崎大学附属図書館に所蔵の写真で

Rice fields near Kinbara now subsided \& destroyed.

[和訳］キンバラ付近の水田は、今では沈下し、大破した。 とする写真説明のある写真注22) 中央に、折損した橋を確認できる。 なお、ダント坂周辺では地震により大規模な崩落が発生した注23)。

以上から、背景となる山の容姿も考慮すると、Photo(1)は日当の素 振谷における反度橋の被災状況について、反度橋に対して素振谷の やや上流南側から北を向き撮影したと判断できる(Photo 2-1)。

\section{3-2 Photo(2)の撮影地点}

\section{3-2-1 Photo(2)の従来の研究}

\section{・『1891濃尾地震報告書』附属CD-r}

『1891濃尾地震報告書』附属CD-rにおいてPhoto(2)は、宮内庁所蔵 のkunai111を所収し、写真題名を“岐阜県下根尾谷橋之図”とする 写真題名が付されるが、具体的な撮影地の説明はない注24)。

\section{3-1-2 Photo(2)の概要と読み取れる情報}

\section{- Photo(2)の概要}

Photo(2)は縦置きで、対岸へ架かる木製橋の被災を示す。写真では 橋桁部分が落下し、一部の部材が対岸下に存置される。

\section{3-2-3 Photo(2)の撮影地点の検討}

Photo(2)に対するGEJの写真解説では注25)

The river here had to be crossed

[和訳］川をここで渡らなければならなかった と寸る。濃尾地震当時、岐阜から根尾谷へ向かった場合、根尾谷筋
で渡橋する地点とは根尾高尾の根尾川下流に渡された高尾橋とする のが妥当である注26)。現状で、この橋は根尾川に設けられ金原ダム の下流に架橋される。写真では光の具合から向かって左側が南、即 ち下流となり、バルトンは本巣市根尾平野の高尾橋東袂から西北西 を向き高尾橋を撮影したと判断できる(Photo 2-2)。

\section{3-3 Photo(3)の撮影地点}

3-3-1 Photo(3)の従来の研究

\section{・『写真でみる濃尾震災』}

『写真でみる濃尾地震』にPhoto(3)が転載され、写真説明には“埋 没した板所の家”、本文では“写真は板所点の惨状を写したものである” 注27) とする。なお、GEJ初版PLATE XX.の写真解説では注28)

NEAR ITASHU, NEODANI.

PLATE XX.

AT one place a group of four or five houses has completely sunk into the earth.

[和訳］：根尾谷イタシュウ近郊

図版20

ある場所では、4、5軒の住宅がまとまって完全に地面に沈み込 んでいる。

として、Photo(3)の撮影を “イタシュウ近郊”とする。なお、根尾谷 において被害の大きかった水鳥付近で“イタシュウ”の地名は存在 せず、隣接して “板所”（現在の根尾板所）が存在するため、『写真 でみる濃尾地震』では、“イタシュウ”を板所に改めたとものと考え られる。但し、『写真でみる濃尾地震』では、板所のどの地点かの記

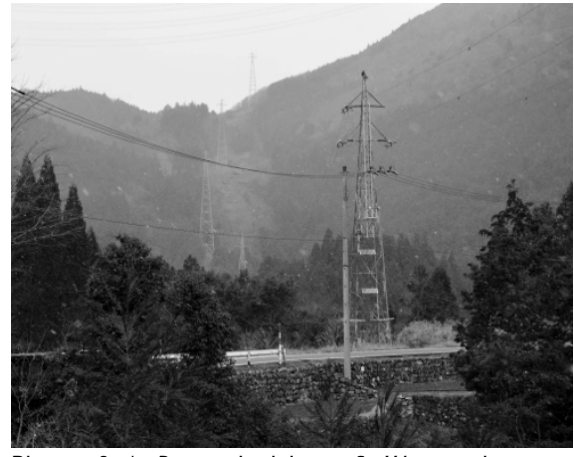

Photo 2-1 Danto bridge of Hinata in Motosu city

反度橋

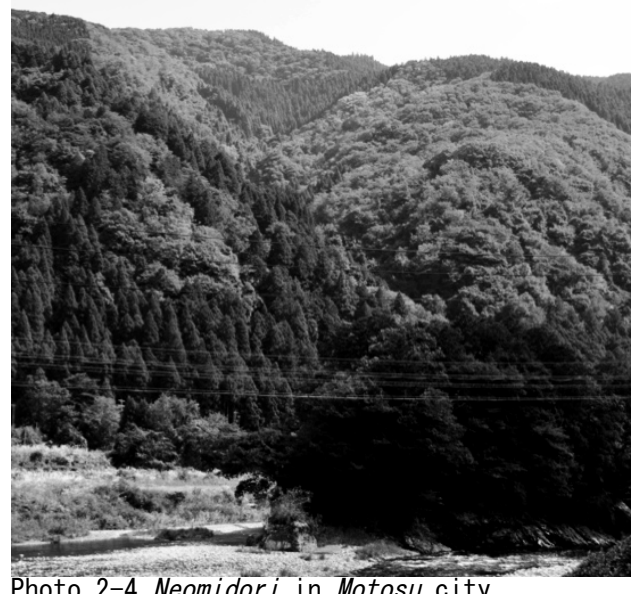

Photo 2-4 Neomidori in Motosu city 根尾水鳥

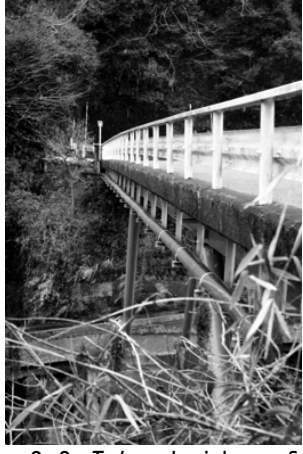

Photo 2-2 Takao bridge of Neohirano in Motosu city 高尾橋

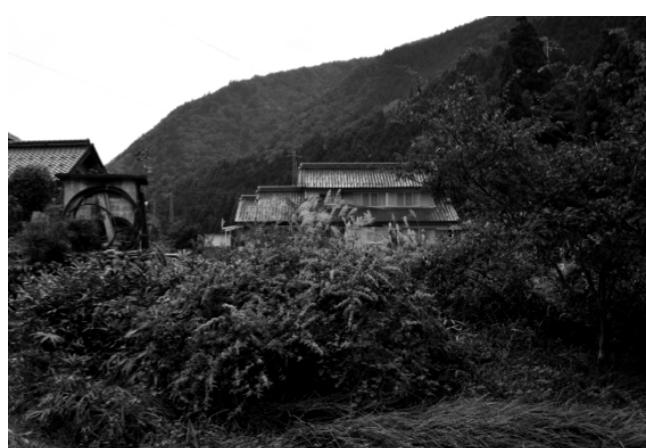

Photo 2-3 Neomidori in Motosu city 根尾水鳥

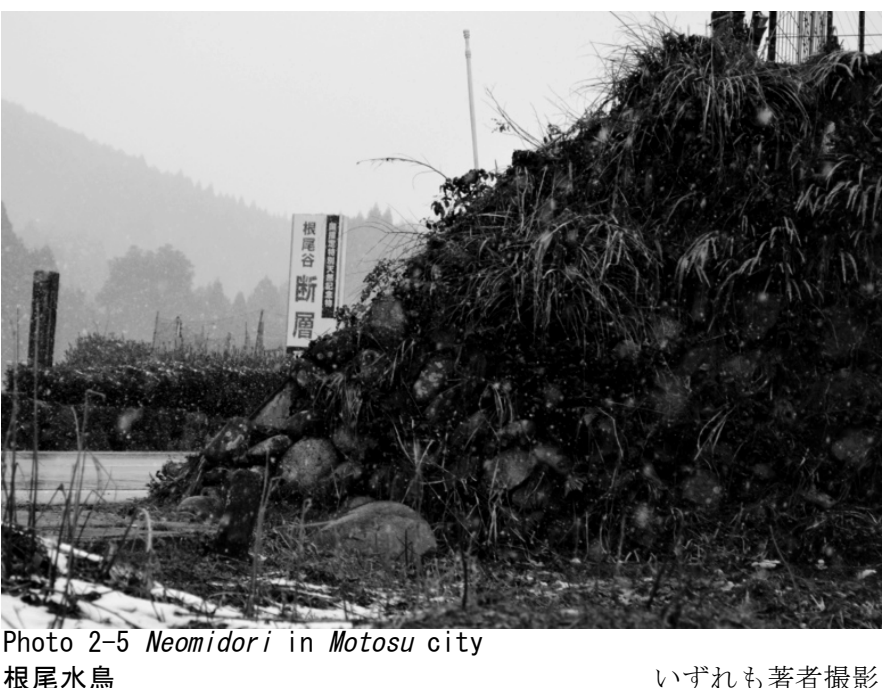


載はない。

\section{• 『THE GREAT NOBI 1891』}

この書籍は、阪神淡路大震災発生後の平成8 (1996) 年に、濃尾地震 後における復興の取り組みを明らかとするためにまとめられ、Photo (3)が転載された $\left.{ }^{2} 29\right) 。$ 写真説明では “板所村の埋没家屋”とされ、 本文では “下の写真のように断層上にあった板所では、家が地中に 落ち込み埋没してしまった”とするが、具体的な地点の指摘はない。

\section{-『三大地震と人々の暮らし 濃尾明治 - 関東大正 ·阪神・淡路現代』}

『三大地震と人々の暮らし』ではPhoto(3)を転載し、“根尾谷の板 州 横浜の写真師・日下部金兵衛の撮影写真である”と解説する注30)。 同書がPhoto(3)を“日下部金兵衛”とするのは、GEJ2版 PRIFACE. [和訳 : 前書 $]$ に注31)

on plate XXI is by Mr. K. Kimbei of Yokohama,

[和訳］：図版21は横浜のK. キンベエによる

とあるためであろう。しかし、GEJ2版 PRIFACE. [和訳 : 前書] にお けるこの文言はGEJ初版にはないため、横浜のK. キンベエ、則ち日下 部金兵衛による撮影は、GEJ2版で差し替えられ、根尾谷断層を南側 から望んだGEJ2版 plate XX. と判断されている注32)。

また、『三大地震と人々の暮らし』では撮影場所を “板州”とする のは、前掲した、GEJ初版PLATE XX.の写真解説における “イタシュ ウ”に漢字を宛てたためと考えられる。但し、根尾谷周辺に “板州” の地名は存在せず注33)、少なくとも板所とすべきであろう。

\section{・『濃尾地震と根尾谷断層』}

『濃尾地震と根尾谷断層』は、根尾谷断層について、当時知り得 る知見を検討し、集大成する目的で平成14 (2002) 年に刊行された学 術書で、写真2-20としてPhoto(3)を引用する。写真説明で “水鳥の断 層崖北端部《中略》水鳥の断層崖の北西部で、低位段丘面の付け根 付近、崩壊した家屋が写し出されている. 南東を望む. 注34)”とある。

\section{・『1891濃尾地震報告書』附属CD-r}

『1891濃尾地震報告書』附属CD-rにおいてPhoto(3)、GEJ2版1刷 を撮影したと考えられるmilne60と、宮内庁所蔵のkunai113を所収す る。kunai113には “岐阜県下根尾谷人家地中陥没之図”之寸る写真 題名が付されるが、具体的な撮影地の説明はない注35)。

\section{3-3-2 Photo(3)の概要と読み取れる情報}

\section{- Photo(3)の概要}

画面では向かって左側に段差が確認でき、これが地震でできた断 層と判断できる。近景から中景では倒壊した茅莫の建物が少なくと も2棟確認でき、断層上にも1棟の茅莫建物がある。建物奥には稲木 で稲を乾燥させる様子を確認できる。遠景には2筋の山裙が見える。

\section{3-3-3 Photo(3)の撮影地点の検討}

Photo(3)との類似から、写真(3)撮影地の反対側からやや離れて撮影 したのが瀬古写真館撮影注 36$)$ の写真と考えることができる。瀬古の 写真では稲木には稲が掛かっていないため、撮影日は瀬古が先行す る。GEJでは瀬古撮影の遠景となる稲木付近から、瀬古の撮影した方 向を向き撮影したと考えられる。方位は瀬古写真館の写真が順光の ため、Photo(3)は南向きでの撮影になる。瀬古の写真の撮影場所は根 尾谷断層の北端部とする注37) ため、水鳥の安立神社西側となる。そ のためPhoto(3)は、本巣市根尾水鳥に所在する安立神社西側の根尾谷 断層北端分付近の落ち込み部で南側を仰いでの撮影となる (Photo $2-3)$ 。
なお、このように考えるとPhoto(3)の撮影地は根尾谷の水鳥とな る。GEJ PLATE XX. の写真解説は “NEAR ITASHU” [和訳 : イタシュウ 近郊］とあり、“イタシュウ”を“板所”としても注意を要する。

\section{3-4 Photo(4)の撮影地点}

\section{3-4-1 Photo(4)の従来の研究}

・『濃尾地震写真資料集』

『濃尾地震写真資料集』は、昭和53 (1978) 年に岐阜県市町村史研 究連絡協議会が岐阜県歴史資料館の指導で、岐皁県を中心とする濃 尾地震の写真資料を発刊し、ここに図2-1としてPhoto(4)を転載した。 写真説明は “水鳥の断層付近から東を向いて撮ったもの”とする注38)

\section{・『写真でみる濃尾震災』}

『写真でみる濃尾震災』においては、Photo(4)を“根尾谷の地す心゙ り”とする写真説明を付し紹介する注39)が、撮影地点の解説はない。 -『三大地震と人々の暮らし 濃尾明治 - 関東大正 - 阪神 - 淡路現代』

『三大地震と人々の暮らし』では “根尾谷における山崩れ” と題 してPhoto(4)を紹介寸る注40)が、具体的な撮影地点の言及はない。

\section{・『濃尾地震と根尾谷断層』}

『濃尾地震と根尾谷断層』においては写真2-28として “七灘対岸 の斜面崩壊”とする写真説明があり、続く説明では “この丘が七灘 の小丘と推定され、東側山地斜面からすべり落ちたものではないと 考えられる” 注41) とする。なお、説明にある “七灘” は地名で、“七 難”注42) と記す場合もある。

\section{・『1891濃尾地震報告書』附属CD-r}

『1891濃尾地震報告書』附属CD-rにおいてPhoto(4)、GEJ2版1刷 を転載したと考えられるmilne62、宮内庁所蔵のkunai114を収める。 この内、kunai114には“岐阜県下根尾谷地之少之図”とする写真題 名が付されるが、具体的な撮影地の説明はない注43)。

\section{3-4-2 Photo(4)の概要と読み取れる情報}

\section{- Photo(4)の概要}

Photo(4)は、写真解説に注44)

THE lighter coloured patches on the sides of mountains shewn in the accompanying plate, are areas which have been denuded of grass and forest by landslips. One of the masses, carrying with it trees in an upright position, which has slipped from above, is seen in the foreground.

[和訳]この図にところどころ見られる山々の斜面上で色の薄い 部分は、地滑りによって草木や森林が剥がされた範囲である。

前方の一箇所では、樹木が立ったまま上から運ばれた様子がわ かる。

とあるように、山の斜面から土砂と樹木が川の中へ運ばれたものを 示している。近景に土砂と樹木が写り、遠景に木及の剥げた山並み を示す。

\section{3-4-3 Photo(4)の撮影地点の検討}

Photo(4)は、『濃尾地震写真資料集』において “水鳥の断層付近か ら東を向いて撮ったもの”との説明される注45)。根尾谷地震断層観 察館への聞き取りで、Photo(4)は根尾谷地震断層観察館から $250 \mathrm{~m}$ 程南 へ寄った根尾川西岸から東側を望んだものとされる(Photo 2-4)。

\section{3-5 Photo(5)の撮影地点}

3-5-1 Photo(5)の従来の研究

-『1891濃尾地震報告書』附属CD-r 
『1891濃尾地震報告書』附属CD-rにおいてPhoto(5)、宮内庁に所 蔵されるkunai115を所収し、“岐阜県下根尾谷地之之図”とする写真 題名が付されるが、具体的な撮影地の説明はない注46)。

\section{3-5-2 Photo(5)の概要と読み取れる情報}

\section{- Photo(5)の概要}

Photo(5)では、画面中央に傾斜のきつい斜面が示され、これは画面 奧まで続く。斜面には握り拳からやや大きい程度の玉石が散乱し、 樹木数本が倒されている。画面向かって左側の低地には道路と考え られるものが写り込み、向かって右側の高地手前には低木が植えら れる。遠景には背後の山並みが写り込む。

\section{3-5-3 Photo(5)の撮影地点の検討}

Photo(5)の転載元となるkunai115の写真題名は、“岐阜県下根尾谷 地之之図”、即ち地滑りの痕跡とする。しかし、Photo(5)を日下金兵 衛が根尾谷断層を南側の高台から撮影し、GEJ 2版PLATE XX. として も掲載される写真と比較すると、以下のことが判明する。

つまり、GEJ 2版PLATE XX.において、現在、県道255号となる道路 が断層に差し掛かる場所において断層の斜面を確認すると、道の両 側では礫が散乱し、道路の向かって右側となる東側斜面を中心に、 断層上部の畑に植えられた桑の木注 47$)$ が数本倒れている。

このように、GEJ 2版PLATE XX. とPhoto(5)は極めて近接した地点を 撮影したと判明することができる。即ちPhoto(5)は、GEJ 2版PLATE XX. に示される様子を断層下部から北西を望んで撮影したものである。 また、Photo(5)に示される斜面は濃尾地震により水鳥に発生した断層 で、これを県道際から北西を向いて撮影したものと判断できる。つ まり、このPhoto(5)、バルトンが工学会において投影した “谷ノ一 方八宿落シ他ノ一方八二十英尺ノ高サニアルモノ”と考えることが できる(Photo 2-5)。

\section{3-6 Photo(6)の撮影地点}

\section{3-6-1 Photo(6)の従来の研究}

\section{・『1891濃尾地震報告書』附属CD-r}

『1891濃尾地震報告書』附属CD-rにおいてPhoto(6)は、宮内庁に所 蔵されるkunai112として所収され、“岐阜県下根尾谷人家之図”とす る写真題名が付されるが、具体的な撮影地の説明はない注48)。

\section{3-6-2 Photo(6)の概要と読み取れる情報}

\section{- Photo(6)の概要}

Photo(6)は、中央に倒壊して茅草の屋根だけ残された民家が示され る。なお、向かって左側に近景に写るのは、やはり倒壊したと考え られる民家の茅莫屋根と考えられる。また、やや離れて倒壊を免れ た小規模な付属屋があり、背景には木々が繁る。

\section{3-6-3 Photo6の撮影地点の検討}

kunai112においてPhoto(6) “岐阜県下根尾谷人家之図”とあるた め、根尾谷における撮影とは判断できる。但し、写真の情報からだ けでは具体的な撮影地点の絞り込みを現段階ではできない。

\section{4. さいごに}

明治24(1891) 年10月28日に発生した濃尾地震後、バルトンが根尾 谷で撮影したと考えられる写真の撮影地点に考察を加えたが、明ら かとなるのは以下の諸点である。

1 ) バルトンが濃尾地震後、根尾谷で撮影した写真としては、GEJ に所収される4枚であるPhoto(1)からPhoto(4)に加え、GEJ未所収で
宮内庁に納められたPhoto(5)、(6の2枚、合計6枚を少なくとも確 認することができる。

2) Photo(1)は本巣市日当の素振谷において、地震により被災した反 度橋を、素振谷のやや上流となる南側から北を向き撮影したもの である。

3 ) Photo(2) は根尾川東岸の本巣市根尾平野、高尾橋東袂から西北西 を向き被災した高尾橋を撮影したものである。

4 ) Photo(3)、本巣市根尾水鳥に所在寸る安立神社西側の根尾谷断 層北端分付近の落ち込み部において、南側を向いて被災した住宅 を撮影したものとなる。

5 ) Photo(4)は、本巣市水鳥に所在する根尾谷地震断層観察館から $250 \mathrm{~m}$ 程南に下った根尾川西岸から東側を望んだものとされている。

6 ) Photo(5)は濃尾地震により水鳥に発生した断層について、県道の 東際から北西を向いて撮影したものである。なお、この写真はバ ルトンが工学会で投影した “谷ノ一方八陥落シ他ノ一方八二十英 尺ノ高サニアルモノ”と考えることができる。

7 ）Photo(6)は根尾谷での撮影と判断できるが撮影地点の絞り込み はできない。

最後に、バルトンがGEJにおいて、日下部金兵衛撮影による根尾谷 断層の写真を採用した背景を考えておきたい。

以上の考察から、バルトンが濃尾地震後の調査により根尾谷おい て“谷ノ一方八陥落シ他ノ一方八二十英尺ノ高サニアルモノ”とす る根尾谷断層を納めたPhoto(5)を撮影したとすることができる。しか し、バルトンは撮影した根尾谷断層のPhoto(5)を、自らも編集に携わ った写真集であるGEJに所収はしなかった。その一方で、根尾谷断層 については、GEJ初版で採用した高尾橋落橋のPhoto(2)の掲載を見送 り、2版で日下部金兵衛撮影による根尾谷断層を南側から撮影した写 真に差し替え出版したこととなる。

バルトンが撮影した根尾谷断層のPhoto(5)と、日下部金兵衛撮影の 根尾谷断層の写真を比較すると、日下部の写真はPhoto(5)をほぼ中心 として、周囲まで広く納めて撮影したことになる。つまり、両写真 では同一の地点を撮影しながら、Photo(5)断層を近距離から、日下 部の写真は遠距離からと、異なる距離と角度からの撮影となってい ることが分かる。

バルトンはGEJにおいて日下部の他、宮下欽、中村牧陽、青山三郎 らにより撮影された写真も用いている。宮下による撮影は木曽川鉄 橋（4枚）、枇杷島鉄橋、北方町の合計6枚で、中村の写真は起村の帝 国大学病院、青山の写真は被災住宅となる。この内、木曾川、北方 町、起村はバルトンの調查経路から外れ主49)、被災住宅は明治 24 (1891) 年12月初旬頃における復興過程を撮影したもの注50)である ため、バルトンによる撮影はかなわなかったものとなる。一方、宮 下の枇杷島鉄橋や日下部の根尾谷断層の写真はバルトンの調查経路 における被写体であったにもかかわらず、バルトン以外の撮影者に よる写真が採用されたこととなる。

宮下撮影による枇杷島鉄橋、日下部撮影による根尾谷断層の2枚が GEJに採用された理由を端的に言えば、バルトンが当該の地において 撮影を行わなかったためで、根尾谷断層の写真について言えば、バ ルトンは日下部が撮影を行った高台に赴いての撮影は行わなかった ため、ということになる。 
加えて、根尾谷を撮影した日下部と、バルトンの撮影によるPhoto (5)を比較すると、2枚の写真ではいずれも断層の高さは認識できるも のの、バルトンの撮影のPhoto(5)は近景からの撮影であるため、断層 の広がりを見ることができない。これに対し、日下部の写真は街道 を歩く人物を写し込む遠景からの撮影であるため、断層の高さに加 え、水鳥付近の平坦地を横断する断層の広がりを一望に把握するこ とができる。その面で、日下部が撮影した写真の方が地震により発 生した断層の様子を示すものとしてPhoto(5)よりも情報量がより多 く、バルトンとしてもこの写真を採用するに至ったものと考えるも のである。

\section{参考文献}

1) John Milne. and W. K. Burton. Plates by K. Ogawa. : The Great Earthquake in Japan, 1891.

2) Central Disaster Prevention Council:1891 Nobi earthquake reports, and CD-r, 2006. 3 (in Japanese)

中央防災会議 災害教訓の継承に関する専門調査会 : 1891 濃尾地震報告書 及び附属 CD-r, 2006. 3

注

注1）平山：J. ミルン、W・K・バルトンによる『THE GREAT EARTHQUAKE IN JAPAN, 1891.』の書誌情報、発刊の経緯、初版及び 2 版の異本について『THE GREAT EARTHQUAKE IN JAPAN，1891.』の研究その 1、日本建築学会計画系論文集 712、1419 1426 頁、平成 27 (2015). 6

注 2) 平山 : 『THE GREAT EARTHQUAKE IN JAPAN, 1891.』新出 2 版 1 刷の発刊 日と装丁者について、日本建築学会技術報告集 53、293 296 頁、平成 29 (2017). 2

注 3）平山：J. ミルン、W・K・バルトンによる『THE GREAT EARTHQUAKE IN JAPAN, 1891.』掲載写真の撮影者について『THE GREAT EARTHQUAKE IN JAPAN，1891.』 の研究その 2、日本建築学会計画系論文集 719、171～177 頁、平成 28 (2016). 1

注 4) 東洋学芸社 : 東洋学芸雑誌 $122 、 585$ 頁、明治 24 (1891). 11

注 5）平山：J. ミルン、W·K・バルトンによる『THE GREAT EARTHQUAKE IN JAPAN, 1891.』掲載写真の撮影者について『THE GREAT EARTHQUAKE IN JAPAN，1891.』 の研究その 2、日本建築学会計画系論文集 $719 、 171 \sim 177$ 頁、前掲

注6) 平山 : 明治24(1891) 年の濃尾地震においてバルトンが撮影した写真の枚 数W·K・バルトンの研究 (67)、日本建築学会北陸支部研究報告集58、357 360 頁、平成 27 (2015). 7

注 7) Photo(1)から Photo(4)は、平山：J. ミルン、W. K. バルトンによる『THE GREAT EARTHQUAKE IN JAPAN, 1891.』掲載写真の撮影者について『THE GREAT EARTHQUAKE IN JAPAN, 1891.』の研究 その 2、日本建築学会計画系論文集 719、171-177 頁、前掲、において、バルトンによる撮影と判断している。 但し、Photo(5)、Photo6については、現段階ではバルトンによる撮影と 考えられる、とするに留まる。そのため本稿では Photo(1)Ｐhoto(6)を一 括して扱う場合、“バルトンが撮影したと考えられる”とする表現を採っ た。

注 8）GEJ2 版ではそれぞれ写真の入れ替えが一部あった。

注 9）工学会：工学会誌 121、本会記事、1 頁及びジョン、ミルン：地震二就 テ、3 頁、明治 25 (1892). 1

注 10）参考文献 1）GEJ “PREFACE.” [ 和訳]前書

注 11）平山：宮内庁所蔵濃尾地震関連写真と他機関所蔵写真におけるバルト

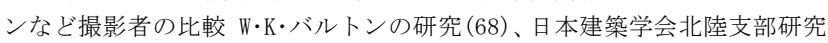
報告集 58、359〜362 頁、平成 27 (2015). 7

注12）参考文献 2) 附属 CD $-r$ kunai115

注13）参考文献 2) 附属 CD $-r$ kunai112

注14）岐阜新聞社：写真でみる濃尾地震、平成 3(1991). 10

注15）岐阜新聞社：写真でみる濃尾地震、32 33 頁、前掲

注16）日本下水文化研究会 : 三大地震と人々の暮らし 濃尾明治・関東大正 · 阪神・淡路現代、平成 8(1996). 7

注17）平山：J. ミルン、W・K・バルトンによる『THE GREAT EARTHQUAKE IN JAPAN, 1891.』の書誌情報、発刊の経緯、初版及び 2 版の異本について『THE GREAT EARTHQUAKE IN JAPAN, 1891.』の研究その 1、日本建築学会計画系論文集 712、1419 1426 頁、前掲

注18) 日本下水文化研究会 : 三大地震と人々の暮らし 濃尾明治・関東大正 .
阪神・淡路現代、46、47 頁、前掲

注19）参考文献 2) 附属 CD-r milne56、kunai110

注 20）参考文献 1）初版 PLATE XVIII. 写真解説

注 21）参考文献 2) 附属 CD $-\mathrm{r}$ gifujma35

注 22）参考文献 2) 附属 CD $-\mathrm{r}$ nagasaki6

注 23）岐阜日日新聞社：岐阜日日新聞、明治 24 (1891). 11/11、2 頁

注 24）参考文献 2）附属 CD-r kunai111

注 25）参考文献 1）初版 PLATE XIX. 写真解説

注 26）根尾谷地変図、岐阜地方気象台所蔵、による。なお、原図には表裏と

も図名は付されない。なお、現状でこの $400 \mathrm{~m}$ ほど下流には新たに高尾橋

が架橋されるがこれとは別のものとなる。

注 27）岐阜新聞社：写真でみる濃尾地震、32３3 頁、前掲

注 28）参考文献 1）初版 PLATE XX. 写真解説

注 29）岐阜県歴史資料館：THE GREAT NOBI EARTHQUAKE 1891 濃尾大震災の

教訓、8 頁、平成 8 (1993). 3。 なお、本書は平成 17 (2005) 年 3 月に復刻版 が出されたが、この 8 頁にPhoto(3)が転載された。

注 30）日本下水文化研究会: 三大地震と人々の暮らし 濃尾明治・関東大正. 阪神・淡路現代、50、51 頁、前掲

注 31）参考文献 1） 2 版 PRIFACE.

注 32）遠藤正治ほか 7 名:濃尾震災の写真-日下金兵衛のアルバムを中心に一、

日本写真芸術学会誌 13-2、17 頁、平成 16(2004). 12

注 33）「角川日本地名大辞典」編纂委員会 : 角川日本地名大辞典 21 岐阜県、 1173 1177 頁、昭和 55 (1980). 9

注 34）村松郁栄 - 松田時彦 - 岡田篤正 : 濃尾地震と根尾谷断層帯-内陸最大 地震と断層の諸性質一、119 頁、平成 14(2002). 3

注 35）参考文献 2）附属 CD-r milne60、kunai113

注 36）参考文献 2）附属 CD-r seko001jpg 及び seko036jpg。なお、宮内庁所 蔵となる kunai256jpg も同一の写真となる。

注 37）村松郁栄・松田時彦 - 岡田篤正 : 濃尾地震と根尾谷断層帯-内陸最大 地震と断層の諸性質一、118 頁、前掲

注 38）岐阜県歴史資料館：濃尾地震写真資料集、2 頁、昭和 53 (1978). 10

注 39）岐阜新聞社：写真でみる濃尾地震、24 頁、前掲

注 40）日本下水文化研究会: 三大地震と人々の暮らし 濃尾明治・関東大正 . 阪神・淡路現代、53 頁、前掲

注 41）村松郁栄 - 松田時彦 - 岡田篤正 : 濃尾地震と根尾谷断層帯-内陸最大 地震と断層の諸性質一、128 頁、前掲

注 42) 本巣郡教育会 : 本巣郡志、岐阜県本巣郡根尾村全図、218 頁の次、昭 和 12 (1937). 11

注 43）参考文献 2）附属 CD-r milne62、kunai114

注 44）参考文献 1）初版 PLATE XXI. 写真解説

注 45）岐阜県歴史資料館：濃尾地震写真資料集、写真 2-1、昭和 53 (1978). 10

注 46）参考文献 2）附属 CD-r kunai115

注 47）佐藤比呂志ほか 3 名：1991 年濃尾活断層系・根尾谷断層（水鳥地区） トレンチ調査、89 頁、活断層研究 11、平成 5(1993)

注 48）参考文献 2）附属 CD-r kunai112

注 49) 平山：W·K・バルトンによる『THE GREAT EARTHQUAKE IN JAPAN, 1891.』 の写真撮影の日程について『THE GREAT EARTHQUAKE IN JAPAN, 1891.』の 研究 その 4、日本建築学会計画系論文集 732、519～525 頁、平成 29 (2017). 2 注 50) 平山: 明治 24 (1891) 年濃尾地震『THE GREAT EARTHQUAKE IN JAPAN, 1891.』 における撮影場所の考察（下） W·K・バルトンの研究 (45)、日本建築学会北 陸支部研究報告集 57、489 頁、平成 26 (2014).7 


\section{STUDY ON THE PHOTOGRAPH AND THE PHOTOGRAPHY PLACE PHOTOGRAPHED IN NEO VALLEY BY W. K. BURTON \\ Study on “THE GREAT EARTHQUAKE IN JAPAN, 1891." part 6}

\section{Ikuo HIRAYAMA*1}

${ }^{* 1}$ Prof., Faculty of Design, Nagaoka Institute of Design, Dr.Eng., Dr.Design

The author has considered the "THE GREAT EARTHQUAKE IN JAPAN, 1891." (hereinafter referred to as GEJ) compiled by W. K. Burton and J. Milne and others at the Nobi Earthquake that occurred on October 28, 1891., and showed that the date of publication of the first edition and the second edition of this book, and 25 sheets of disaster area photographs were taken by Burton. By the way, among the photos of the GEJ collection, there are some of the four photos taken at Neo valley where specific photography spots were not considered. Meanwhile, Barton shot 72 pictures in the disaster area, but there were 25 photos taken to GEJ, and there were possibilities that there were phots taken in the Neo valley in 47 unfilled pieces. Therefore this article showed the photos which were not put in GEJ although Burton photographed in Neo valley.

The photos which Burton shot in the Nobi earthquake stricken area of Neo valley of the GEJ collection are four pieces of first edition PLATE XVIII. (Photo (1)), first edition PLATE XIX. (Photo (2), first edition PLATE XX. (Photo (3)) and first edition PLATE XXI. (Photo (4)). After the Nobi earthquake, Burton reflected and explained the filmslides in the Japan Federation of Engineering Societies held on November 25, 1891, he reflected the photograph which was not unfilled in GEJ, and "one fell, and the other was the amount of 20 feet" here (Photo(5)). There is the photograph which has titled "Gihukenka-Neodani-zinka-no-zu" (Photo (6),possessed at the Imperial Household Agency and without the second use, and this photograph is regarded as shot by Burton.

Photo(1) was shot the Danto bridge, Photo(2) was shot the Takao bridge, Photo(3) was shot the afflicted houses beside the Adati shrine, Photo(4) was shot the Neo river. Photo(5) was shot the fault caused by the Nobi earthquake at Midori. The shooting location of Photo(6) is unknown. 